\title{
Schools of Government's roles and challenges for institutionalization: a comparative study in the Brazilian Federal Public Sector
}

Diogo Ribeiro da Fonseca

Universidade de Brasília (UnB)

\section{Marizaura Reis de Souza Camões}

Universidade de Brasília (UnB)

Pedro Luiz Costa Cavalcante

Instituto de Pesquisa Econômica Aplicada (IPEA)

Joselene Lemos

Escola Nacional de Administração Pública (Enap)

Pedro Palotti

Instituto de Pesquisa Econômica Aplicada (IPEA)

The role of Schools of Government has been relatively vague in the literature and in several countries' public administrations. Consequently, schools operate in normative contexts that do not address their specific needs and purposes as educational entities. The present study seeks to comparatively describe institutional, strategic and educational characteristics of 17 Brazilian Federal Schools of Government to define aspects for their distinctive characterization. The qualitative research was based in document analysis and structured interviews with heads in schools. The results present a common identity between schools, as well as differences regarding their configurations. We attempt to propose a typology for the sampled schools which, we suggest, may be used as a means for a general theory for the comprehension of varying characteristics between schools of government, relating to their roles and formats. The study contributes to a better understanding regarding the role of schools of government and proposes further research to support their institutionalization and development. Sector.

Keywords: Schools of Government, Human Resource Development, Training, Public

[Artigo recebido em 30 de junho de 2016. Aprovado em 24 de maio de 2018.] 
O Papel das Escolas de Governo e desafios para sua institucionalização: um estudo comparativo no Setor Público Federal Brasileiro.

O papel das Escolas de Governo é descrito de forma relativamente vaga na literatura e nas administrações públicas de diversos países. Consequentemente, as escolas operam em contextos normativos que não atendem suas necessidades e propósitos específicos como entidades educacionais. O presente estudo visou descrever e comparar características institucionais, estratégicas e educacionais de 17 Escolas de Governo Federais no Brasil e definir aspectos para sua caracterização distintiva. A pesquisa, de natureza qualitativa, baseou-se em análises documentais e entrevistas estruturadas com dirigentes das escolas. Os resultados demonstram a identidade comum das escolas, bem como diferenças em relação às suas configurações. Propõe-se uma tipologia para a amostra de escolas de governo, de forma a subsidiar teorias para compreensão do seu perfil, seus papéis e formatos organizacionais. O estudo contribui para uma melhor compreensão acerca do papel das Escolas de Governo e propõe novas pesquisas que forneçam suporte à sua institucionalização e resolução de obstáculos ao seu desenvolvimento.

Palavras-Chave: Escolas de Governo; Desenvolvimento de Pessoal; Treinamento; Setor Público.

\section{El papel de las Escuelas de Gobierno y desafíos para su institucionalización: un estudio comparativo en el Sector Público Federal Brasileño.}

El papel de las Escuelas de Gobierno ha sido descrito de forma relativamente vaga en la literatura y en las administraciones públicas de varios países. Consecuentemente, las escuelas operan en contextos normativos que no atienden sus necesidades y propósitos específicos como entidades educativas. El presente estudio busca describir y comparar las características institucionales, estratégicas y educativas de 17 Escuelas de Gobierno Federales en Brasil y definir aspectos para su caracterización distintiva. La investigación, de enfoque cualitativo, se basó en el análisis documental y en entrevistas estructuradas con los directores de las escuelas. Los resultados presentan la identidad común entre las escuelas, así como diferencias en cuanto a sus configuraciones. Se propone una tipología para las escuelas de la muestra para subsidiar teorías para la comprensión de su perfil, sus papeles y formatos organizacionales. El estudio contribuye a una mejor comprensión del papel de las escuelas de gobierno y propone nuevas investigaciones como un medio para apoyar su institucionalización y la resolución de los obstáculos a su desarrollo.

Palabras-clave: Escuelas de Gobierno; Desarollo de Personal; Entrenamiento; Sector Público. 


\section{Introduction}

The public bureaucracy is one of the institutional pillars to an efficient functioning of the democratic system and application of the State of Law. On one hand, a board of professional public employees enables greater continuity, coherence and relevance to public policies while ensuring higher impartiality and objectivity to public entities. On the other hand, a poorly staffed and unskilled bureaucratic body tends to generate inefficiency and misuse of public resources (Stein et al., 2006).

The Brazilian Federal Government, since the late 1980's, has been investing in continuous training for professionalization of bureaucratic careers (Fernandes, 2015). In this process, besides traditional training departments in public organizations, a broad variety of Schools of Government has been created aiming at improving government performance (Cavalcante; Carvalho, 2017; Fernandes, 2015). The observed heterogeneity of these institutions showed that there has been certain ambiguity relating to the concept and role of Schools of Government (Pacheco, 2000; 2002). Without clear criteria for the role and format of this type of organization, there has been a proliferation of institutions referred to as Schools of Government (Cavalcante; Carvalho, 2017; Pacheco, 2002). A recent survey in the Brazilian context (Fonseca et al., 2015) investigated a universe comprised by, at least, 260 institutions dedicated to training activities, with varying characteristics, in different government spheres and branches.

Likewise, a recent cross-national study carried out by the OECD's Global Network of Schools of Government initiative (OECD, 2017) highlights differing governance models among schools of government in several countries and supports the conclusion that there are no preconceived models for these organizations. Hence, besides the heterogeneity of schools in the Brazilian public sector, a larger set of schools in the international scenario also stands as a potential subject for more systematic and comparative research. A consistent research agenda for the development of a theoretical framework about schools of government, therefore, might constitute an important advance for the improvement of their performance, as well as their institutionalization and legitimation as a strategic tool for building state capacities (Fernandes, 2015; OECD, 2017; Pacheco, 2000).

From a local and professional point of view, the enactment of the National Personnel Development Policy - NPDP (Brasil, 2006) gave higher priority to training activities as a strategy for the modernization of the Brazilian public sector. This policy attributed a fundamental role to schools of government on developing necessary competences in public organizations and seeking long-term cooperation in the provision of training (Brasil, 2006). However, an integrative and cooperative 
personnel development policy requires greater knowledge about the schools of government comprising the federal public service (Carvalho, 2012).

The present study stands besides recent efforts to better describe and define the role of schools of government (e.g. OECD, 2017; Fernandes, 2017; Fonseca et al., 2015; Rosa; Hollanda, 2017). As an introductory comparative study, the research, carried out in the Brazilian Federal Government, sought to answer the following research question: what are the institutional, strategic and educational characteristics of the Schools of Government and what aspects serve as criteria for their distinctive characterization from other educational and training institutions, such as traditional and corporate universities?

In view of these theoretical gaps and professional challenges, the present study aims to provide parameters for the disambiguation of the concept and functions of Schools of Government and to subsidize the achievement of NPDP's objectives, which remained, so far, mostly unattended (Camões; Meneses, 2016).

\section{Schools of government: a myriad of formats, roles and activities.}

The increasing demand for training as a means to reach growing standards of competence and performance in the public sector required, throughout the development of public administration, the creation of specialized institutions for the qualification and permanent development of public servants. Fernandes (2017) reviews the main studies that sought to describe the characteristics of the institutions dedicated to the education of public servants in several countries.

According to Fernandes (2017) most studies regard surveys for comparison among national organizations, while others focus on innovations and best training practices without concern for the specific analysis of organizations. The author notes that the term "School of Government" is not commonly used, with the exception of more recent studies (e.g. Prescott, 2014, OECD, 2017), indicating that this concept hasn't been widespread in the literature itself. Worthy of mention is that few of the reviewed studies are peer reviewed papers in scientific journals, being most of them research reports and professional publications.

The review shows that most studies find a great diversity of organizational formats regarding institutions dedicated to the education of public servants. They may take the form of public administration schools, public bodies, government agencies (Pollitt; Op de Beeck, 2010) or even private institutions (Kolisnichenko, 2005). In general, no single model is regarded as ideal (Hall, 2002) and the choice for a specific arrangement is related to differing national contexts and policy preferences regarding governance, management and administration of 
public organizations and civil service personnel (Rosa; Hollanda, 2017; OECD, 2017). In this regard, some countries adopt arrangements where a single institution within government centralizes the formulation and implementation of educational policies. Another set of countries has several government institutions coordinated for this purpose, while others share the responsibility for educational policies with non-governmental stakeholders (OECD, 2017). The choice of the institutional model relates to the format, legal nature and position of the schools within the public service. These aspects may, therefore, also affect their roles, institutional relationships, technical and managerial autonomy and the degree of entrepreneurship or outsourcing in their activities (Fernandes, 2017; OECD, 2017; Verhoest et al, 2004).

Regarding their activities, the schools may adopt different approaches to the development of the public sector. The OECD (2017) report, as well as studies regarding the Brazilian context (e.g. Cavalcante; Carvalho, 2017; Pacheco, 2000), allow for the distinction of at least three different sets of activities: Training, Education and Research. The schools may adopt several approaches to workforce development, usually varying in relation to an emphasis in formal education or professional training (Reichard, 1998). Formal education (e.g. specializations, post-graduations) regards foundational knowledge for civil servants at the time of recruitment, or during their career, envisioning long-term applications. The approach regarding training and professional development provides specific skills that civil servants need in their current jobs, relating to a short-term performance. While these development functions are prevalent among schools, some schools (near $50 \%$ in the OECD survey) may also engage in knowledge production through research and knowledge activities. Knowledge development and research activities are aimed at fostering innovation, improving public services, and leading institutional and organizational changes.

Further distinctions noted by Fernandes (2017) in the literature regarding preentry training and in-service (Lucking, 2003), technical and managerial (leadership), and generalist and specialized training (Reichard, 1998; Prescott, 2014). Regarding the hiring of teachers, schools often rely on external professionals to design and conduct their courses (Hall, 2002). Currently, schools usually seek a mix between public servants with professional experience and academics at the senior level (Pollitt; Op de Beeck, 2010).

The heterogeneity presented by the diverse institutional models for schools of government leads Fernandes (2017) to assert that most studies do not hold a clear concept for these institutions. In view of these differing conceptualizations, he deduces that schools of government are generally regarded as institutions 
within the public administration focused on the training of public servants, but primarily dedicated to the development of senior civil servants (Fernandes, 2017). Pacheco (2000; 2002), seeking a definition for the Brazilian context, broadly defines schools of government as those institutions dedicated to the development of civil servants, embedded in the state apparatus or heavily financed by public resources. Given these are provisional definitions, and emphasize single dimensions - respectively activities and institutional formats - the suggested approach to a better theoretical development regarding the schools of government is the exhaustive investigation of relevant factors and dimensions for their adequate description and systematic comparison.

Comparative studies in public administration have become an important tool for theory building and testing in a field often threatened by parochialism and unscientific claims (Fitzpatrick et al, 2011; Sigelman, 2006). Comparative studies are often characterized by qualitative approaches, aimed at the definition and description of concepts, variables and constructs that constitute meaningful dimensions of comparison among differing units (countries, states, public bodies) (Sigelman, 2006).

Fernandes (2017) literature review and Pacheco's (2000) research agenda provide some dimensions and factors relating to schools' characteristics: organizational formats and models; degrees of autonomy; target audiences; staffing methods; insertion in the public administration; institutional relationships; sources of financing; balance between training, education and research; educational objectives, content and methods and; degree of alignment with government strategies and policies.

In order to avoid an atheoretical approach in our analysis, besides the reviewed empirical literature on schools of government, we attempt to ground the above mentioned variables in a few well-developed theories from public administration and human resource development fields. We refer to definitions of organizational autonomy by Verhoest et al (2004), which in their seminal article were able to define multiple analytical dimensions and levels, including institutional, structural, managerial and political factors affecting public organizations. This theoretical framework has been used in comparative studies involving various countries (e.g. Verhoest et al, 2010), mainly in Europe, which allowed for validation of the factors involved in the comparative analysis of autonomy in public organizations in different contexts.

While Public Administration theories refer to context and structure, comparative studies regarding Personnel (Human Resource) Development must define "organization- specific" systems and routines, in order to evaluate their interrelation with the context (Wang \& Sun, 2012). In this regard, we draw aspects from 
corporate universities literature (Meister, 1999) and, among theoretical premises regarding the public service, we highlight the concept of HRD functions, brought by studies in the British Civil Service, referring to the functions of: provision of specialized knowledge - as centres of excellence - provision of shared services and formation of strategic partnerships (Stewart et al, 2010).

Since cross-national studies might yield a great variation and a consequent difficulty in direct comparisons, the investigation proposed by this article takes advantage of a sample of schools located within the same institutional context. Although context-specific, the findings regarding the schools of government in the Brazilian context may lead to more systematic results and attempt to contribute to the theoretical refinement regarding the roles and formats of these institutions.

\section{Schools of Government in the Brazilian Context}

The Brazilian Federal Government has given higher priority to personnel development through the enactment of the Decree N. 5.707/2006, which created the National Personnel Development Policy - NPDP (Política Nacional de Desenvolvimento de Pessoal). In the Decree's scope, as a way to make NPDP more effective, the Federal Schools of Government System (Sistema de Escolas de Governo da União - SEGU), was created with the main objectives of improving civil service training through partnerships and cooperation among schools of government (Camões \& Meneses; 2016; Cavalcante; Carvalho, 2017). This initiative, which is coordinated by the National School of Public Administration (Escola Nacional de Administração Pública - ENAP) aims to establish long-term cooperation in training activities among schools of government and public organization's training departments.

The perspectives brought by SEGU are similar to those brought by the National Schools of Government Network. The National Network was informally created by ENAP in 2003 and aimed at increasing the effectiveness of institutions that work with the training and professional development in the public service (Cavalcante; Carvalho, 2017). The arrangement was regarded as a tool for sharing experiences and establishing partnerships at the federal, state and municipal levels of the Executive, Legislative and Judiciary Powers. The National Network is formed by Schools of Government, Training Centers, Universities, Corporate Universities, Secretariats of State and Municipal Administrations and other interested institutions. It had a significant increase in the number of members (from 49 institutions in 2003 to 260 in 2016) and in developed activities (Fernandes, 2015). According to a study by Fonseca et al (2015), in addition to the National Network, schools in different sectors and spheres of government have local networks of collaboration. Among 
the 118 survey participant schools, 63\% reported participation in other training networks. A total of 29 networks were identified, with approximately 739 entities (Figure 1). The depiction of the National Network corroborates the complexity of the Brazilian context (OECD, 2017) and supports the search for a more comprehensive theoretical framework for the study and management of schools of government (Carvalho, 2012; Fernandes, 2015; 2017) 
Figure 1: Network depiction of the Interface between "National Schools of Government Network" participants and other development networks. Source: Adapted from Fonseca et al (2015). Free Translation.

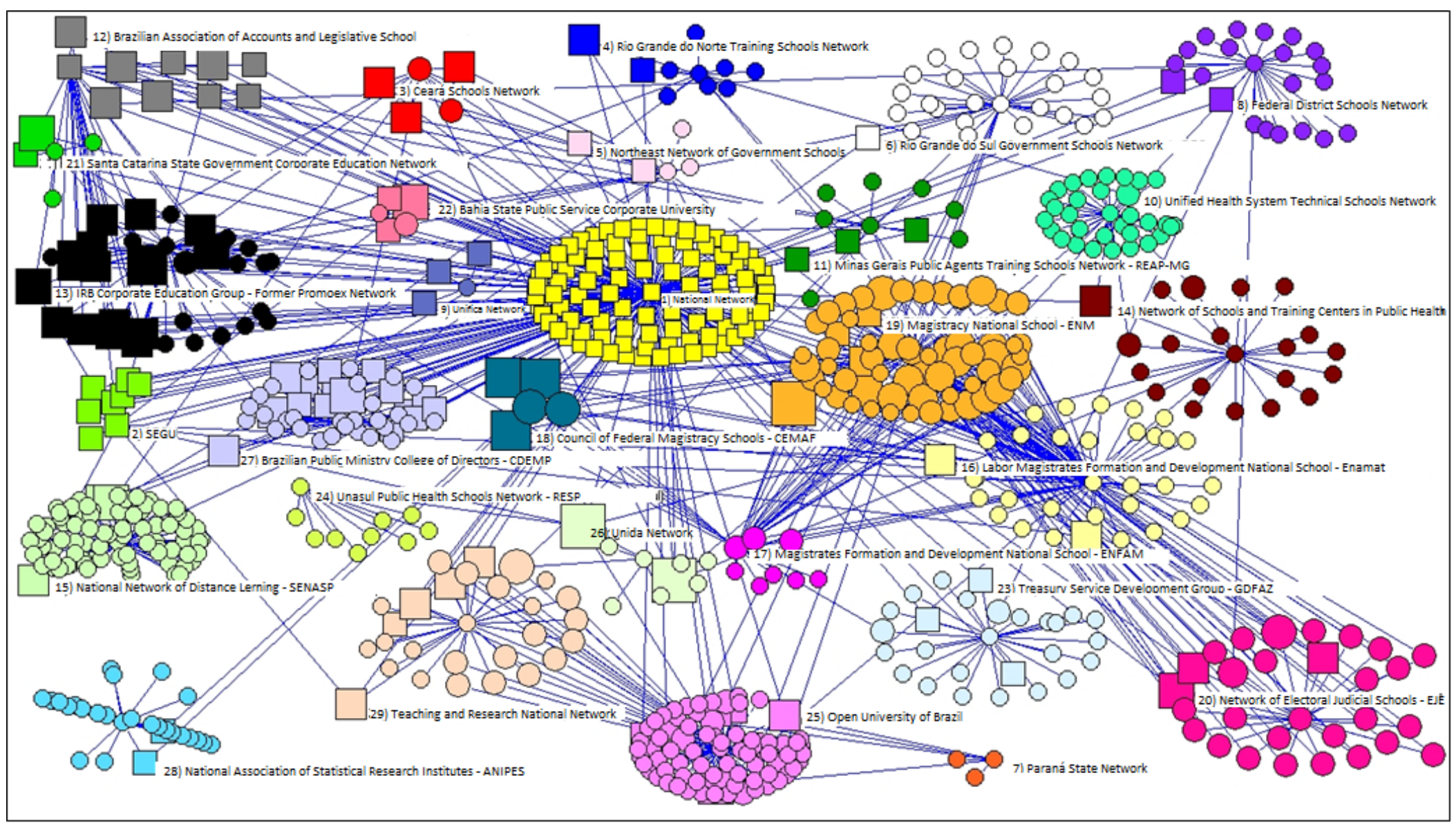


While the National Schools of Government Network has few normative foundations, within the scope of the PNDP, ENAP is defined as the central entity for the articulation of the Federal Schools of Government System (SEGU). The heterogeneity among the institutions within both networks is regarded as a shortcoming for their coordination and definition of common agendas (Carvalho, 2012). In this regard, the present research seeks to establish theoretical and empirical foundations for a deeper knowledge about the Brazilian schools of government. The research was carried out on all 17 Schools of Government that were part of SEGU in 2015, regarded as the federal schools of government core.

The study compares institutional, strategic and educational dimensions of the organizations in order to identify common and varying characteristics and challenges regarding their role and objectives in public service. Hence, as its main objective, the study seeks to highlight differences and similarities between these institutions and provide parameters for the comparison and disambiguation of the concept and functions of Schools of Government. The results may as well provide a better comprehension of schools of government in the wider national and international scenarios.

\section{Methods}

The research has a descriptive-exploratory approach with a qualitative crosssectional analysis and was carried out within the period from December 2013 to November 2014. The structure of the research is divided analytically into three dimensions, which correspond to aspects defined as relevant by Fernandes (2017).

1) Political-institutional dimension: to describe the formal and structural characteristics of the schools of government and their location in the Federal Public Administration.

2) Strategic dimension: to describe guidelines, roles, related policy fields and target audiences of the schools.

3) Educational dimension: to describe educational and research activities carried out by the schools.

These dimensions also refer to common distinctions of levels and dimensions of analysis in comparative research, between institutional, organizational and technical level (Wang \& Sun, 2012). These usually involve different theoretical frameworks and approaches, which are relatively abundant in the inherently interdisciplinary field of comparative public administration (Heady, 2006). 


\subsection{Sampled Schools of Government}

The sampled organizations encompassed all 17 schools of government that comprised the SEGU at the time of research. The location of schools in the public sector defines two types of institutional relationships: supervision and subordination.

All schools are located within the jurisdiction of a central government body, encompassing ministries in the executive branch and the chamber of deputies and the senate in the legislative branch. These central government bodies have a supervisory function, which oversees and controls activities in the school's field of activity. The linkage is administrative in nature and pertains to sectoral coordination, without necessarily entailing subordination. For those schools located within a government body or agency there is a subordination relationship to its maintaining organization, where schools may take the format of an internal autonomous organization or a department. Table 1 depicts the 17 schools and their respective institutional relationships, regarding the respective maintaining organizations, supervisory bodies and government branches. Besides each institution's name their original acronym is presented.

Considering the research objectives, two complementary stages of data collection were designed to gather distinct information as a means to compare the listed schools. The first stage consisted in a document analysis to extract thematic nuclei from the main norms and regulations of each school. The second stage was comprised of interviews with the school's managers and directors to collect descriptions about the reality of the institutions, concerning their educational and management routines and political processes which characterize their activities.

\subsection{Document Analysis}

Data collection for document analysis consisted of a list of 13 broad categories of documents defined by the documents that constituted ENAP's legal and normative framework, taken as a reference for the investigation of the remaining schools. The documents were formally requested by ENAP to each school. Alternatively, official government websites were prospected to complement each institution's document database. There was a total of 135 documents which addressed general and specific norms and regulations of all schools of government. The types of documents collected and the number of schools in which they were found are described in Table 2. 
Table 1 - Brazilian Federal Schools of Government comprising the Federal Schools of Government System, and respective maintaining organizations, supervisory bodies and government branches. Source: Document Research Data

\begin{tabular}{|c|c|c|c|c|}
\hline N. & School of Government & Maintaining Organization & Supervisory Body & Branch \\
\hline 1 & National Police Academy (ANP) & $\begin{array}{l}\text { Federal Police Department } \\
\text { (DPF) }\end{array}$ & Ministry of Justice (MJ) & Executive \\
\hline 2 & $\begin{array}{l}\text { Center for Advanced Studies of the National } \\
\text { Treasury Attorney-General's Office. (CEAE) }\end{array}$ & $\begin{array}{l}\text { National Treasury Attorney- } \\
\text { General's Office (PGFN) }\end{array}$ & $\begin{array}{l}\text { Attorney-General of the } \\
\text { Union's Office (AGU) }\end{array}$ & Independent \\
\hline 3 & $\begin{array}{l}\text { Center for Formation and Improvement of the } \\
\text { National Institute of Social Security (CFAI) }\end{array}$ & $\begin{array}{l}\text { National Institute of Social } \\
\text { Security (INSS) }\end{array}$ & $\begin{array}{l}\text { Ministry of Social Welfare } \\
\text { (MPS) }\end{array}$ & Executive \\
\hline 4 & $\begin{array}{l}\text { School of the Attorney-General of the Union's Office } \\
\text { (EAGU) }\end{array}$ & $\begin{array}{l}\text { Attorney-General of the Union's } \\
\text { Office (AGU) }\end{array}$ & $\begin{array}{l}\text { Attorney-General of the } \\
\text { Union's Office (AGU) }\end{array}$ & Executive \\
\hline 8 & $\begin{array}{l}\text { National School of Mediation and Conciliation } \\
\text { (ENAM) }\end{array}$ & Ministry of Justice (MJ) & Ministry of Justice (MJ) & Executive \\
\hline 7 & $\begin{array}{l}\text { National Public Administration School } \\
\text { (ENAP) }\end{array}$ & - & $\begin{array}{l}\text { Ministry of Planning, } \\
\text { Accounting and } \\
\text { Management (MP) }\end{array}$ & Executive \\
\hline 9 & National School of Statistical Sciences (ENCE) & $\begin{array}{l}\text { Brazilian Institute of Geography } \\
\text { and Statistics (IBGE) }\end{array}$ & $\begin{array}{l}\text { Ministry of Planning, } \\
\text { Accounting and } \\
\text { Management (MP) }\end{array}$ & Executive \\
\hline 10 & $\begin{array}{l}\text { National School of Public Health Sérgio Arouca } \\
\text { (ENSP) }\end{array}$ & $\begin{array}{l}\text { Oswaldo Cruz Foundation } \\
\text { (FIOCRUZ) }\end{array}$ & Ministry of Health (MS) & Executive \\
\hline 5 & Superior Finance Administration School (ESAF) & Ministry of Economy (MF) & Ministry of Economy (MF) & Executive \\
\hline 6 & School of Intelligence (ESINT) & $\begin{array}{l}\text { Brazilian Intelligence Agency } \\
\text { (ABIN) }\end{array}$ & $\begin{array}{l}\text { Institutional Security } \\
\text { Cabinet of the Presidency } \\
\text { (GSI) }\end{array}$ & Executive \\
\hline 11 & National School of Penintentiary Services (ESPEN) & $\begin{array}{l}\text { National Penintentiary } \\
\text { Departament (DEPEN) }\end{array}$ & Ministry of Justice (MJ) & Executive \\
\hline 12 & Joaquim Nabuco Foundation (FUNDAJ) & - & Ministry of Educaiton (MEC) & Executive \\
\hline 13 & Rio Branco Institute (IRBR) & $\begin{array}{l}\text { Ministry of External Relations } \\
\text { (MRE) }\end{array}$ & $\begin{array}{l}\text { Ministry of External } \\
\text { Relations (MRE) }\end{array}$ & Executive \\
\hline 14 & University of the Central Bank of Brazil (UNIBACEN) & Central Bank of Brazil (BACEN) & Ministry of Economy (MF) & Executive \\
\hline 15 & Serzedello Corrêa Institute (ISC) & Federal Court of Accounts (TCU) & Senate & Legislative \\
\hline 16 & Senate's Brazilian Legislative Institute (ILB) & Senate & Senate & Legislative \\
\hline 17 & $\begin{array}{l}\text { Chamber of Deputies' Center for Formation, Training } \\
\text { and Improvement (CEFOR) }\end{array}$ & Chamber of Deputies & Chamber of Deputies & Legislative \\
\hline
\end{tabular}


Table 2 - Document types and respective number of schools presenting them. Source; Research Data.

Type of Document

Schools Proportion

1a) Regimental Structure - Supervisory Body

$17 \quad 100 \%$

1b) Regimental Structure - Maintaining Organization

$1271 \%$

1c) Regimental Structure - School of Government

2a) Internal Rules - Supervisory Body

$424 \%$

2b) Internal Rules - Maintaining Organization

$15 \quad 88 \%$

2c) Internal Rules - School of Government 14 $82 \%$

3a) Organizational Structure - Supervisory Body 12 $71 \%$

3b) Organizational Structure - Maintaining Organization 15 13

3c) Organizational Structure - School of Government

3d) Activities of the School's organizational units 11 12

3e) Schools' number of public servants and Employees 10

4) Schools' Founding Law/Norm 15

5) Educational Policy 12

11

$88 \%$

6) Strategic Plans

4

7a) Mngt. Plans - Information Technology Plan/Policy

7b) Mngt. Plans - Human Resource Management Plan/ Policy

1

7c) Mngt. Plans - Annual Training Programs (2012 and 2013);

7d) Mngt. Plans - Knowledge Management Policy

8) Management Reports (2012)

9) Institutional Development Plan - IDP

10) Related Careers' Laws

11) Preceding Studies

12) Partnerships and cooperation agreements

13) Related Legislation

14) Other Documents

$\begin{array}{cc}2 & 12 \% \\ 17 & 100 \% \\ 6 & 35 \% \\ 16 & 94 \% \\ 5 & 29 \% \\ 10 & 59 \% \\ 9 & 53 \% \\ 7 & 41 \%\end{array}$


The documents were analyzed through content analysis, and their excerpts and articles categorized according to the subject they referred to. Based on this analysis the formally defined institutional characteristics, mandates, goals, activities and forms of organization were, then, attributed to each school.

\subsection{Interviews}

The interviews were undertaken after the document analysis and had the objective of detailing the description of schools. The sample of interviewees was intentional in nature, having as criterion the participation of the head of the school or an indicated substitute. It was admitted more than one interview by school in order that different sections of the questionnaire could be answered by several managers, provided that they had experience with the theme. The research instrument was a standardized interview script for all schools with questions regarding the three dimensions of analysis: politicalinstitutional, strategic and educational traits of schools. The questions sought to collect the perception of the managers about the identity of schools of government, autonomy, institutional relationships and also descriptions regarding schools' activities, guidelines, and managerial and technical aspects of educational activities. Data collection consisted of 37 interviews with 41 school managers, which were transcribed and coded.

\section{Results}

Document analysis showed great variation among schools, especially regarding their location, formats, autonomy, target audiences and educational strategies. Data from the interviews complemented the analysis with a perspective closer to the reality of schools. The results are presented according to the proposed analytical dimensions, regarding institutional, strategic and educational characteristics of the schools. Afterwards, aspects regarding the role of schools are highlighted, aiming to delineate a common and distinctive identity of these institutions. The differences between schools, on the other hand, allowed for the proposition of an initial typology, with nine categories of schools representing their strategic and educational roles as stated in part of the literature (OECD, 2017; Reichard, 1998)

\subsection{Institutional Dimension}

The institutional dimension describes the formal and structural characteristics of schools. Based on document analysis the schools are compared in relation to their location in the public administration, their formats and functions, hierarchical position, legal framework and financial autonomy. For each of these aspects the schools can be ordered from higher to lower legal status, positions and degree of autonomy. These aspects are discussed below and summarized in Figure 1. 
Figure 2: Institutional Characteristics and Location of Brazilian Federal Schools of Government in the Public Service. Source: Document Research Data

\section{Federal Schools of Government System}

Institutional Relations, Legal Framework and Hierarchical Position in the Federal Public Adminsitration

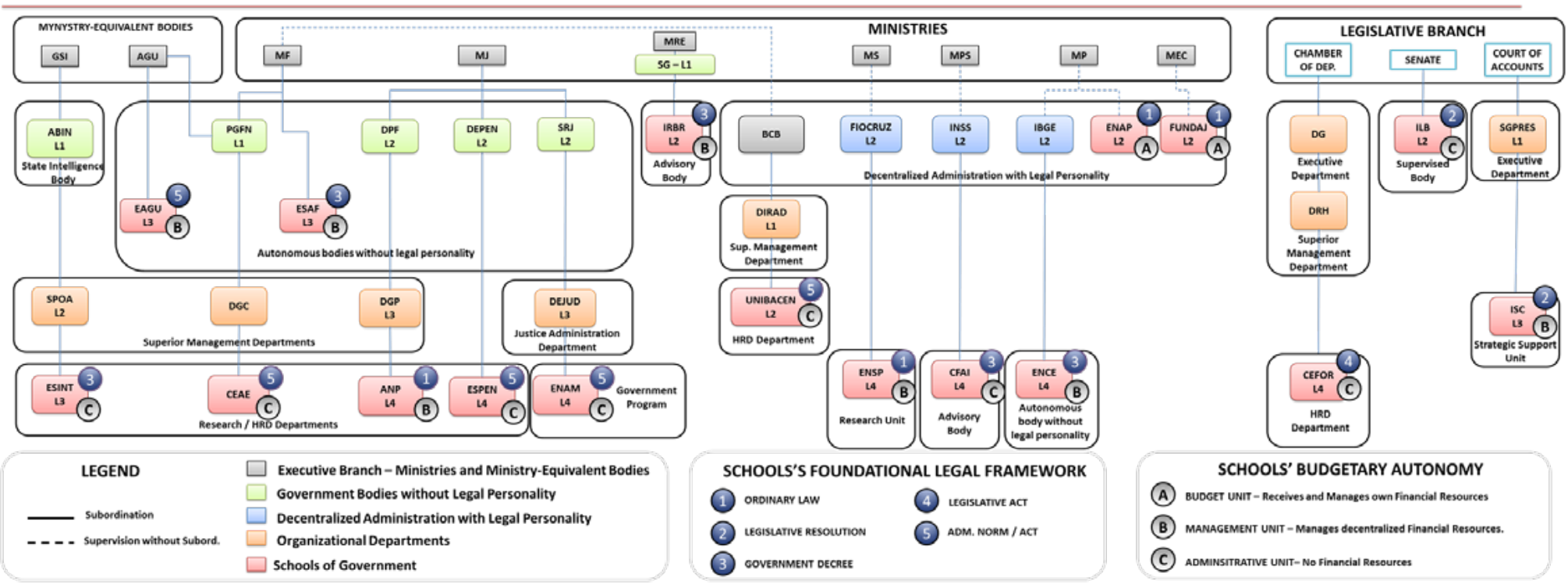




\subsubsection{Location of Schools and formats.}

The location of schools relates to their institutional framework, which defines relationships between the schools and government institutions (OECD, 2017). In the present research, these relationships are defined in terms of subordination and supervision in accordance to the Brazilian administrative legislation.

As described in Figure 2 the schools currently are located in different levels in the public service structure, which ultimately impacts on their legal nature and format. Location not always reflects the hierarchical position of the head of the school which will be described below. Hence, instead of hierarchical position, we define three tiers where schools can be located, relating to how many superior bodies and departments a school has, and to which it is subordinated.

The first tier encompasses schools without subordination to any superior organization and is represented by ENAP and FUNDAJ. This is due to their unique legal nature as autonomous decentralized organizations with public legal personality, being ENAP a public foundation and FUNDAJ an autarchy. These are the only schools who are autonomous organizations themselves. The remainder of schools is located inside their maintaining organizations' structure, be they government departments or agencies.

Therefore, the second tier comprises organizations directly subordinated to the head of their maintaining organization and is represented by 08 schools: EAGU, ESAF, IRBR, ENSP, CFAI, ENCE in the executive branch and by ILB and ISC in the legislative branch. These schools vary in their function, as defined by their legal framework. Part of these schools are a separate structure and function as autonomous organizations within a government body (EAGU, ESAF, ENCE). ENSP has a similar format, although it is formally defined as a Research Unit within its maintaining organization. In this tier, operating within their maintaining organization's structure, there are schools formally defined as advisory bodies (IRBR, CFAI), strategic support units (ISC) or supervised bodies (ILB).

The third and lower tier comprises schools located within the structure of their maintaining organizations, but that are subordinated to intermediate executive or administrative departments. There are 07 schools in this location and, most of them are formally defined as Human Resource Development (HRD) Departments (ESINT, ANP, ESPEN, UNIBACEN, CEFOR) meaning they fulfill an internal role of training the maintaining organization bureaucracy. Besides these organizations, but still with an internal orientation, the CEAE has a broader mandate, being regarded as "unit for development, articulation and research". The only school in this tier with a different format is ENAM, which is defined as a part of a government program and is focused on the training and education of audiences external to their maintaining organization. 


\subsubsection{Head of Schools' Position in Hierarchy}

The hierarchy system in the Brazilian public sector is defined by a command line consisting of formal positions. The highest position pertains to executive secretaries under the ministries or similar high-level executives in the public organizations. For the purpose of this research, and as a matter of describing the existing different hierarchical systems with general categories, we define four hierarchical levels in accordance with research data. The first level in hierarchy, pertaining to top executives is referred a "L1" and the subsequent lower levels are referred as "L2", L3" and "L4". Based on the formal positions occupied by the heads of the schools, none of them has a "L1" position. The second hierarchical level (L2) is occupied by heads in 05 schools (ENAP, FUNDAJ, IRBR, ILB, UNIBACEN). Since, ENAP and FUNDAJ are autonomous and decentralized public organizations, we can infer that the remainder of schools in this hierarchical level have a similar autonomy, relating to the decision-making powers of their heads, despite their formats and mandates. The third hierarchical level (L3) is occupied by heads of 04 schools (EAGU, ESAF, ESINT, ISC). The fourth pertains to heads of 07 schools (ANP, ESPEN, ENAM, ENSP, CFAI, ENCE, CEFOR) and finally, CEAE is the only school to which no formal executive position has been assigned. As stated above, the formats and locations of schools do not directly translate in a higher or lower hierarchical position of their heads. Some relations within these aspects might be inferred, since there are no schools with an HRD function with high-level positions, as there are no autonomous organizations/bodies with lower-level positions. To some extent, therefore, the hierarchical position of schools may reflect to whom the schools respond to in terms of training priorities (OECD, 2017). Schools higher in the hierarchy may have a greater participation in strategic formulation, while those in lower hierarchical positions might be focused on implementation and execution of planned activities. Another explanation, following the hierarchical principle, is that the hierarchical position reflects the span of control and responsibilities a given school has.

\subsubsection{Budgetary Autonomy}

Budgetary autonomy is formally defined in the Brazilian legislation. Hence, each school is classified in one of three formal categories, as described below from the most to the least autonomous:

a. Budget Unit: The school is directly funded by government and has discretionary powers over its own resources (ENAP and FUNDAJ);

b. Management Unit: the school has discretionary power over resources decentralized by a maintaining organization (EAGU, ESAF, IRBR, ANP, ISC, and ENCE); 
c. Administrative Unit: the school has no financial resources and depends on its provision by the maintaining organization, which centralizes its management (ESINT, CEAE, ESPEN, ENAM, UNIBACEN, CFAI, CEFOR, and ILB).

Following the same pattern of other variables, ENAP and FUNDAJ have a higher status regarding their financial autonomy, which is due to their legal nature. For the remainder of schools their budgetary autonomy varies and seems to follow their organizational formats. For instance, those schools that are organized as autonomous organizations (EAGU, ESAF, ENCE, ENSP) are Management Units, meaning they don't directly receive resources - given they don't have legal personality - but they can freely manage what is provided by their maintaining organizations. Nonetheless, for the reminder of schools there is no clear relation with their formats and budgetary autonomy. In this sense, as another dimension of institutional autonomy, this aspect may reflect to what extent a school is regarded more as an internal department or as a relatively autonomous educational institution.

\subsubsection{Legal Framework}

The last analyzed aspect refers to the legal framework of schools. The legal instrument that establishes the school influences its authority and defines its mandate and capacities (OECD, 2017). On the other side, the strength of the legal instrument that regulates the school also defines the extent to which the government can alter its status and decision-making competencies (Verhoest et al., 2004). For instance, changes in schools created by an ordinary law must be the subject of legislative processes while those created by organization ordinance may be extinguished or modified by an administrative act issued by the head of the organization. In this regard, the Brazilian legislation defines a hierarchy between norms, ranging from constitutional norms, government decrees to internal administrative rules and acts. The analyzed schools were classified according to five categories of regulating legal instruments found in the research and ordered by their strength:

1. Ordinary Law: ENAP, FUNDAJ, ANP, and ENSP.

2. Legislative Resolution: ILB and ISC.

3. Government Decree: ESINT, ESAF, IRBR, CFAI and ENCE.

4. Legislative Act: CEFOR.

5. Administrative Norm/Act: EAGU, CEAE, ESPEN, ENAM, and UNIBACEN,

Data suggests that schools with broader roles are usually created by specific laws and decrees or within the legal instrument of their maintaining organization, as an intended part of its structure. The more solemn legal instruments, with the 
participation of the head of the executive and/or the legislative branch, may be regarded not only as a legal safeguard but as a source of legitimacy. Schools created by more precarious norms would be more vulnerable to loss of legitimacy and autonomy or extinction.

The analyzed institutional aspects, therefore, show there is a great variety of governance models for the schools. The institutional distance between schools, ranging from autonomous educational institutions to HRD departments, depicts the large difference there is regarding their autonomy, capabilities and functions. Although ENAP and FUNDAJ stand as the most autonomous and strategically positioned schools, it is not sought by this research to objectively rank the institutions based on their institutional characteristics. Nonetheless, since the analyzed dimensions comprehend ordinal categorical variables, further theoretical developments may lead to an evaluation model of the schools' institutional factors and clarify the impacts they have on their performance.

\subsection{Strategic Dimension}

The present section shows results relating to the strategic positioning of schools, in regard to their mission statements and target audiences. Formally defined strategies were found only in some schools' documents. In view of this, part of gathered data refers to formal statements found in the school's documents, while another part has been reported by the schools during document data collection. After that, during the interviews' phase of research, complementary information about each school's activities and target audiences were collected and compared.

\subsubsection{Mission Statements}

Mission statements refer to the School of Government's role and purpose and identifies the target audience they seek to support on the attainment of objectives. Document analysis showed that 11 schools (ANP, CFAI, EAGU, ESINT, ENAP, ENCE, UNIBACEN, ISC, ILB, CEFOR and ENAM) had updated strategic plans. Nonetheless, mission statements, endorsed by their respective interviewees, where mostly found in other documents. The Institutional Development Plan was the main document to define strategic and mission statements in six schools (ANP, CFAI, ENAP, ESAF, ESINT, ISC). Other documents that defined the school's mission were the Strategic Plan (ENAM, FUNDAJ), Management Reports (ENCE, ENSP) and legal instruments such as schools' Regimental Structure (IRBR, CEFOR), Internal Rules (ESPEN) and creation norm (ILB). Finally, those schools that didn't have a formal mission statement, provided a mission statement as perceived by their managers (CEAE, EAGU, UNIBACEN). 
Each mission statement was analyzed and coded in regard to the level of their activities meant to have an impact. The first level implicated missions which targeted improvement of results in their maintaining organizations (M.O.), with an internally oriented function. This category encompassed 07 schools (CEAE, CFAI, EAGU, IRBR, UNIBACEN, ILB, and CEFOR). Four schools had their mission statements aimed at improving results in the policy field level, meaning a group of organizations with a mandate in a given public sector activity, such as public health or public safety (ANP, ESINT, ENSP, ESPEN). Three schools aimed at improving results the public administration level, that is, all public organizations (ESAF, ENAP, ISC). At last, three schools mission statements aimed at broader societal objectives, which we coded as society-level objectives (ENCE, FUNDAJ, ENAM). The collected mission statements are shown in Table 3. 


\section{Table 3 - Mission Statements of schools, target audiences inferred by researchers and sources}

School Mission Statements / Main Objectives

ANP To train and specialize public security professionals to excellently perform their duties, as well as formulate and disseminate police doctrine in defense of society.

To promote the professional qualification and the development of the PGFN's public servants aiming

CEAE at the technical, juridical and scientific specialization of the members of the organ, promoting the academic discussion of topics related to its activities.

Promote the development of skills and disseminate social security knowledge, contributing to the valorization of public servants and the continuous improvement of the services provided.

To permanently promote the development of people, aiming at the excellence of the AGU in the exercise of its constitutional attributions.

ESAF Develop people for the improvement of the management of the public finances and the promotion of citizenship.

ESINT

To train and develop human resources for the exercise of Intelligence activity.

ENAP

Develop skills of public servants to increase the government capacity in the management of public policies.

ENCE Provide teaching, research and quality extension and contribute to the production and dissemination of statistical and geographical information in Brazil

Generate, absorb, share and disseminate scientific and technological knowledge in public health,

ENSP through research and development, education, technical-specialized cooperation and provision of assistance services, aiming at improving the population's health conditions and promoting quality of life.

Promote and execute strategies for initial and continued training, research, doctrine formulation and professional improvement in criminal and production services, and sharing of knowledge in public policies aimed at the prison system.

FUNDAJ Promote scientific, cultural and educational activities, seeking the advancement of Brazilian society in social, educational, political and economic achievements.

The recruitment, selection, training and training of Diplomatic Career personnel and execution of

IRBR special programs for the training of higher education careers of the Ministry of Foreign Affairs and related areas;

UNIBACEN "Manage corporate education and promote knowledge management aiming at the development of competencies in the Central Bank of Brazil."

ISC Develop skills for the control of public management

Conceive, formulate, execute and evaluate the training of human resources, including the strategic advanced study programs in agreement with other parliaments. Plan, promote, execute and evaluate programs and activities of recruitment, selection, improvement, specialization and development of human resources.

Policy Field

Maintaining

Organization

Maintaining

Organization

Maintaining

Organization

Public

Administration

Policy Field

Public

Administration

Society

Policy Field /

Society

Policy Field

Society

Maintaining

Organization

Maintaining

Organization

Public

Administration

Maintaining

Organization

Maintaining

Organization

Society
Source

Document

Analysis (9)

Provided by School

Document

Analysis (9)

Provided by

School

Document

Analysis (9)

Document

Analysis (9)

Document

Analysis (9)

Document

Analysis (8)

Document

Analysis (8)

Document

Analysis (2c)

Document

Analysis (6)

Document

Analysis (1c)

Provided by

School

Document

Analysis (9)

Document

Analysis (4)

Document

Analysis (1c)

Document

Analysis (6) 


\subsubsection{Target Audiences}

After the definition and analysis of mission statements, the interviews with managers provided complementary information regarding the schools' thematic field and target audiences. Table 4 shows the schools' main thematic fields, target audiences and a comparison with the focused level of their missions, as coded by the researchers.

Table 4 - Government schools' thematic field and target audiences. Source: Interview Research data

\begin{tabular}{|c|c|c|c|c|c|}
\hline \multirow[t]{2}{*}{ N. } & \multirow{2}{*}{$\begin{array}{l}\text { School of } \\
\text { Government }\end{array}$} & \multirow{2}{*}{$\begin{array}{l}\text { Focused Policy/ } \\
\text { Thematic Field }\end{array}$} & \multicolumn{2}{|c|}{$\begin{array}{c}\text { Amplitude of Target } \\
\text { Audience }\end{array}$} & \multirow{2}{*}{$\begin{array}{c}\text { Mission } \\
\text { Statement } \\
\text { Target }\end{array}$} \\
\hline & & & Primary & Secondary & \\
\hline 1 & ANP & $\begin{array}{l}\text { Public Safety and } \\
\text { Police Sciences }\end{array}$ & M.O. & $\begin{array}{l}\text { Public Safety } \\
\text { Policy Field }\end{array}$ & Policy Field \\
\hline 2 & CEAE & Tax Law & M.O. & - & M.O. \\
\hline 3 & CFAI & Social Security & M.O. & Society & M.O. \\
\hline 4 & EAGU & Public Law & M.O. & - & M.O. \\
\hline 5 & ENAM & $\begin{array}{l}\text { Judicial } \\
\text { Mediation and } \\
\text { Reconciliation }\end{array}$ & $\begin{array}{l}\text { Justice } \\
\text { System }\end{array}$ & Society & Society \\
\hline 6 & ENAP & $\begin{array}{l}\text { Public Policy } \\
\text { Management }\end{array}$ & S.B. & $\begin{array}{l}\text { Federal Public } \\
\text { Administration }\end{array}$ & Pub. Adm. \\
\hline 7 & ENCE & $\begin{array}{l}\text { Statistics and } \\
\text { Geography }\end{array}$ & M.O. & Society & Society \\
\hline 8 & ENSP & $\begin{array}{l}\text { Public Health and } \\
\text { Technology }\end{array}$ & S.B. & $\begin{array}{l}\text { Federal and } \\
\text { Local Health } \\
\text { Systems }\end{array}$ & $\begin{array}{l}\text { Policy Field } \\
\text { / Society }\end{array}$ \\
\hline 9 & ESAF & Public Finances & M.O. & $\begin{array}{l}\text { Federal Public } \\
\text { Administration }\end{array}$ & Pub. Adm. \\
\hline 10 & ESINT & $\begin{array}{l}\text { "State } \\
\text { Intelligence } \\
\text { and Counter- } \\
\text { Intelligence" }\end{array}$ & M.O. & $\begin{array}{c}\text { State } \\
\text { Intelligence } \\
\text { Policy Field }\end{array}$ & Policy Field \\
\hline 11 & ESPEN & $\begin{array}{l}\text { Penitentiary } \\
\text { System }\end{array}$ & M.O. & $\begin{array}{c}\text { Federal } \\
\text { and Local } \\
\text { Penintentiary } \\
\text { Systems }\end{array}$ & Policy Field \\
\hline 12 & FUNDAJ & Social Sciences & S.B. & Society & Society \\
\hline 13 & IRBR & Diplomacy & M.O. & - & M.O. \\
\hline 14 & UNIBACEN & $\begin{array}{l}\text { Economy and } \\
\text { Public Finances }\end{array}$ & M.O. & - & M.O. \\
\hline
\end{tabular}




\begin{tabular}{cclccc}
\hline 15 & ISC & $\begin{array}{l}\text { Public Sector } \\
\text { Audit and } \\
\text { Control }\end{array}$ & M.O. & $\begin{array}{l}\text { Federal Public } \\
\text { Administration }\end{array}$ & Pub. Adm. \\
\hline 16 & ILB & $\begin{array}{l}\text { Legislative } \\
\text { Matter }\end{array}$ & M.O. & $\begin{array}{l}\text { Legislative } \\
\text { Branch and } \\
\text { Society }\end{array}$ & M.O. \\
\hline 17 & CEFOR & $\begin{array}{l}\text { Legislative } \\
\text { Matter }\end{array}$ & M.O. & Society & M.O. \\
M.O. = Maintaining Organization & & & \\
S.B. = Supervisory Body (Ministry) & &
\end{tabular}

School's themes range from typical government activities (e.g. IRBR, ESINT) to general themes applied to the context of public policies (e.g., FUNDAJ, ENCE). The primary target audience encompasses organizations directly supported by the educational actions of government schools. The secondary (external) target audience refers to organizations and actors located outside the immediate environment of the school, however, that have their needs systematically attended by them.

Schools, in general, have one or more organizations for which they offer educational actions. There are schools that primarily attend to the demands of their maintaining organization (CEAE, EAGU, IRBR, UNIBACEN), in a way that there is no structured attendance to other organizations. Another group of schools, besides their own maintaining organization, also provides regular courses for other organizations in their field of activity (ANP, ESINT, ESPEN, ILB, ISC, ESAF), and/or for society at large (CFAI, ILB, CEFOR, ENCE). Another group of schools has a more aligned relationship with their Supervisory Bodies (ENAP, FUNDAJ, ENSP). Thus, they won't focus on meeting specific organizational needs. Rather, their focus rests on the needs arising from specific public policies linked to their supervisory bodies (S.B.). In this regard, they are responsible for the development of specific educational solutions for the various organizations involved in the target public policy. As a last case, ENAM is characterized by not having an organization as a primary target audience, attending to a set of actors that are part of the national Justice System and society at large.

Considering the data gathered from the interviews, all 17 schools agree that their main role is the training, development and education of public servants. However, part of the interviewees defended the existence of a "double role" in their schools, referring to other complementary activities that they carry out in parallel to the typical training activity. ENAP highlighted the role of institutional coordination and articulation of cooperation networks between schools of government. Other schools are divided between public servant training activities and other key organizational processes, such as academic activities, development and publication of scientific research, and evaluation of public policies (ENSP, FUNDAJ, ENCE). That 
said, differences in objectives and the specific forms of carrying out educational activities were observed among schools, as described in the next section.

\subsection{Educational Dimension}

The educational dimension describes which educational activities are realized by the Schools of Government. Besides the activities predicted in their norms, the categorization of data originated from the interviews with school managers, as they provided a more in-depth view of routines. The activities performed by the schools as outlined in these interviews allowed for the identification of three sets of activities: Training, Education and Research. Training refers to current job performance, comprising technical and managerial training. Education activities relate to long-term courses for future professional activities or improvement of educational levels (Reichard, 1998). Such category should include the following types of courses: specialized entry-level and career-related courses, formal education encompassing graduation, lato sensu degrees - specialization - and stricto sensu degrees - i.e. Master's and Doctorate (Fernandes, 2017). At last, Research regards a set of activities aimed at the development and promotion of studies in the school's primary policy fields, as well as publications in professional or technical-scientific journals (OECD, 2017). Such division in categories, outlined by activities initially mapped in document analysis, was individually validated by schools through the interviews undertaken with managers, ratifying the common use of the applied terminology. Table 5 presents interview data regarding which activities are formally performed by the schools.

It was observed that a set of schools emphasized training activities with no reported activities classified as education (ENAM, CEAE, CFAI, ESINT). At first glance, the distinction between technical and managerial training was not relevant between schools. Within the scope of educational activities, encompassing career formation and formal education, some differences between schools emerge. $A$ set of schools (ANP, EAGU, ESAF, ENAP, ESPEN, ISC, UNIBACEN and ILB) provides lato sensu courses, seen as an advanced professional improvement. Other group is known for providing stricto sensu courses (CEFOR, FUNDAJ, IRBR, ENSP and ENCE) which present an academic perspective, not necessarily related to job performance. In this context, IRBR can be pointed out as a school focused on professional and educational formation, with no provision of technical and management training. 
Table 5 - Set of activities performed by schools. Source: Interview research data.

\begin{tabular}{|c|c|c|c|c|c|c|c|c|}
\hline \multirow{3}{*}{ Schools } & \multicolumn{2}{|c|}{ Training } & \multicolumn{4}{|c|}{ Education } & \multicolumn{2}{|c|}{ Research } \\
\hline & \multirow{2}{*}{ Technical } & \multirow{2}{*}{ Manag. } & \multicolumn{4}{|c|}{$\begin{array}{c}\text { Formal Education } \\
\text { Degrees }\end{array}$} & \multirow{2}{*}{ Research } & \multirow{2}{*}{ Publishing } \\
\hline & & & Formation & Grad. & $\begin{array}{l}\text { Lato } \\
\text { Sensu }\end{array}$ & $\begin{array}{l}\text { Stricto } \\
\text { Sensu }\end{array}$ & & \\
\hline ENAM & $x$ & & & & & & $x$ & $x$ \\
\hline CEAE & $x$ & $x$ & & & & & $x$ & $x$ \\
\hline CFAI & $x$ & $x$ & & & & & & \\
\hline ESINT & $x$ & $x$ & $x$ & & & & $x$ & $x$ \\
\hline ANP & $x$ & $x$ & $x$ & & $x$ & & $x$ & $x$ \\
\hline EAGU & $x$ & $x$ & $x$ & & $x$ & & $x$ & $x$ \\
\hline ESAF & $x$ & $x$ & $x$ & & $x$ & & $x$ & $x$ \\
\hline ENAP & $x$ & $x$ & $x$ & & $x$ & & $x$ & $x$ \\
\hline ESPEN & $x$ & $x$ & $x$ & & $x$ & & $x$ & \\
\hline ISC & $x$ & $x$ & $x$ & & $x$ & & $x$ & \\
\hline UNIBACEN & $x$ & $x$ & & & $x$ & & & \\
\hline ILB & $x$ & $x$ & & & $x$ & & & \\
\hline CEFOR & $x$ & & & & $x$ & $x$ & $x$ & $x$ \\
\hline FUNDAJ & $x$ & $x$ & $x$ & & $x$ & $x$ & $x$ & $x$ \\
\hline ENSP & $x$ & $x$ & & & $x$ & $x$ & $x$ & $x$ \\
\hline ENCE & $x$ & $x$ & $x$ & $x$ & $x$ & $x$ & $x$ & $x$ \\
\hline IRBR & & & $x$ & & $x$ & $x$ & $x$ & $x$ \\
\hline
\end{tabular}

With respect to research activities, an even distribution was verified, regardless of the emphasized educational activities in schools. However, apparently there are evidences that more consistent research activities are a consequence of the provision of stricto sensu courses. Such affirmation is based on information given during interviews that researches and publications would be a consequence of studies performed by students, research teams and departments in the school structure.

The results until the present section attempted to show the differences in priorities and roles between schools, reflecting, to some extent, distinct organizational, institutional, strategic and educational environments. As stated initially, a direct 
and systematic comparison of schools is, in this sense, difficult as verified in other researches (e.g. OECD, 2017; Rosa; Hollanda, 2017). Nonetheless, some aspects can be useful for a proposition of a classification typology that takes into account the range of differences between schools within their role as educational entities.

\subsection{Federal Schools of Government Typology}

In order to organize fundamental similarities and differences between schools of government, some variables can be taken as a meaningful indication of their respective strategic guidelines and roles, which allows for a classification of schools based on their characteristics.

The classification typology of schools of government was performed by combining two variables: target audience and scope of educational actions provided. Theoretically, the target audience can be regarded as the amplitude of the schools' activities and to which actors the school responds to, reflecting, to some extent its format, role and institutional characteristics. From these institutional aspects derives the target audience emphasis. Based on empirical data, usually schools with an HRD role will seek to address internal needs, while those that are regarded as support units and bodies may have a more direct and frequent connection with public policies, being responsible for the training of an external audience.

Target Audience we, hence, analyzed in three categories: i) mainly employees from their immediate maintaining organization (internal audience); ii) mainly employees of other public organizations, collaborators and citizens (external audience); and iii) both, encompassing not only public employees, but also private entities and citizens, as long as these are regularly provided with training and education and not eventually (internal and external audience).

The second variable regards a typical theoretical distinction between Training and Education in the public service (OECD, 2017; Reichard, 1998). These reflect the approach a given school has in relation to what type of knowledge is needed in government and the emphasis on short term or long term development and performance of public servants. Hence, educational activities were also divided into three categories, by scope, whose definitions were previously provided: i) training, ii) education, and iii) both: training and education, with consistent offer of courses related to both types of activities.

The proposed typology is represented by the comparison of categories of targetaudience (horizontal axis) and scope of educational activities (vertical axis) as seen in Figure 3. The crossing of three categories of each axis defines nine quadrants (from " $A$ " to " $I$ ") describing the schools of government's profile. There is no progression or opposition between the types of schools, only a depiction of their educational 
scope (training and education) and target audience (internal and external). The intermediary quadrants encompass the mixed categories of each variable.

Figure 3 - Classification and typology of schools of government based on scope of educational activities and target audiences. Source: Research data

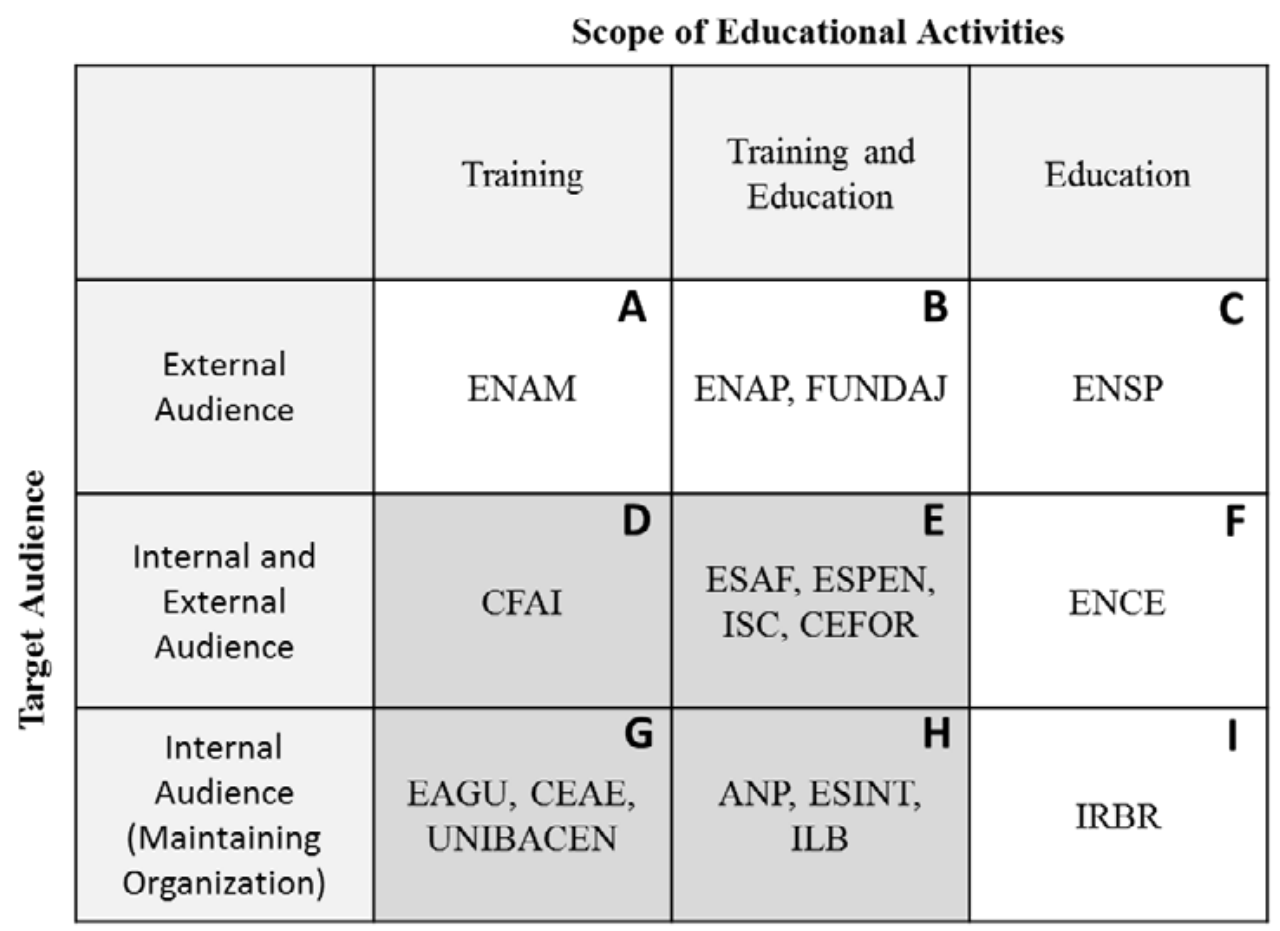

The presented typology demonstrates that a set of schools are mainly oriented to fulfill their internal public needs, without providing systematic training and educational service to external demands (Quadrants $\mathrm{G}, \mathrm{H}$ and I). The schools presenting the profiles given by quadrants " $D$ ", " $E$ " and " $F$ " address their internal public, but present a structure for systematic attendance to external demands from other public organizations (Esaf, Espen, ISC) or the overall society (CFAI, Cefor, Ence). At last, in quadrants " $A$ ", " $B$ " and " $C$ " there are schools addressing whole policy fields or the entire government, and less a specific institution (Enam, Enap, Fundaj, ENSP).

With respect to educational actions, the schools vary in regard to emphasis on training, aiming at enhancing employees performance on current jobs (Quadrants $A, D$ and $G$ ), and emphasis on professional and academic formation, aiming at the development of long term competences and knowledge ( $C, F$ and I). There are intermediary ( $\mathrm{B}, \mathrm{E}$ and $\mathrm{H}$ ) schools which provide formation courses as well as 
graduate studies in a regular basis, but keeping certain focus on the improvement of professional performance through the training of civil servants.

According to some reports there is an overall trend between schools from Quadrants " $D$ ", " $G$ " and " $H$ " to seek a profile presented by Quadrant " $E$ " with the extension of their training and education activities to external audiences with a systematic and regular provision of courses. Most schools classified in these quadrants correspond to those originated from former human resources training departments in their organizations, initially focused on their internal needs, which gradually consolidated in a specialized and more autonomous structure that currently characterizes themselves as schools of government.

The remaining outer Quadrants " $A$ ", " $B$ ", " $C$ ", " $F$ " and "I" encompass schools of government with very specific histories of creation, trajectories and functions. These schools were normally created in the context of major changes in public administration and linked to specific public policies or support to sectoral restructuration (e.g. ENAM). As shown by results regarding the institutional dimension, these schools tend to present greater autonomy and to operate in different government spheres. In some cases, the heads of these organizations are even formally designated as members of policy formulation committees in their maintaining organizations (ENSP, ENCE) and Ministries (ENAP).

Therefore, the proposed typology shows the differences of priority and roles for each school, reflecting their distinct organizational, institutional and strategic environments. As an initial attempt of classification, along with other possible classifications, the presented typology might require further development and may not well reflect the reality in some schools. Nonetheless, its improvement may lead to a broader theoretical framework, encompassing more relevant variables that reflect a school's role and providing a tool for its adequate management that take in consideration its differences.

In spite of the results and the current perception in literature that schools are largely different (e.g. OECD, 2017; Fernandes, 2017; Carvalho, 2012, Rosa; Hollanda, 2017), the present research was able to outline points of convergence between those institutions which favor the conception of a common identity and a guideline for its distinct characterization.

\subsection{Strategic commonalities between Federal Schools of Government}

This study shows that schools of government present great configuration diversity, which reflect their creation histories and trajectories. The schools' general objectives converge, however, in a group of transversal characteristics which outline the identity shared among these institutions. 
In order to define the common functions of schools of government, it was identified through document analysis their primary statutory activities, based on respective structuring norms and regulations. Six recurring competencies in the legislation were found, which serve as a reference to identify the functions institutionally attributed to schools of government in general ${ }^{1}$ :

I. Employees career training (17 schools)

II. Cooperation with public, private, national and international organizations (15)

III. Development and promotion of studies and researches (14)

IV. Knowledge management and publishing (9)

V. Provision of specialized advisory services in respective policy fields (7)

VI. Provision of educational actions to society in general (6)

Therefore, formally and empirically, the schools of government activities are mainly focused on training, formation and education of public employees, as well as on the generation and diffusion of scientific and technical knowledge and information. This result corroborates with international surveys such as the OECD's (2017) and Fernandes' (2017) concept. At a first glance, the analysis of the schools of government's activities may characterize them as traditional education and research organizations. However, their goals will determine differences in their role as schools of government. There are fundamental differences regarding the objectives of educational activities carried out by the schools and specific ways to perform such activities, which poses them as an organization distinct from traditional or corporate universities, as well as regular training departments.

In this respect, the analysis of the information provided by the interviewed managers allowed for the identification of common criteria elicited by the Schools in the definition of their role as Schools of Government. The criteria are shown in Table 6, ordered by frequency. According to interviewed managers the schools of government:

\footnotetext{
1 "Recruitment and Selection" competence observed in five schools (ANP, Esaf, IRBR, ISC and Cefor) was not considered essential, since it does not regard an educational activity and is not necessarily a fundamental function of a school of government, although it might pose as an important process in their context.
} 
Table 6 - Role characterization criteria for Schools of Government. Source: Research data

\begin{tabular}{l} 
Criterion $\begin{array}{l}\text { Definition } \\
\text { "According to interviewed managers the schools of } \\
\text { government should:" } \\
\text { Promote the formation and training of public employees and } \\
\text { agents who contribute to public service activities and results. }\end{array}$ \\
$\begin{array}{l}\text { Target Audience } \\
\text { Thematic Field }\end{array}$ \\
$\begin{array}{l}\text { Contribute to improve the performance of public } \\
\text { administration. }\end{array}$ \\
\hline Objective \\
Strategic \\
Operate in parallel to the objectives of public organizations \\
and policies. \\
Connection
\end{tabular}

Formality

Are formally established by laws, norms and regulations.

Publicization

Promote the diffusion of information of public interest.

Based on the opinion of the interviewees, we can infer that the status of "school of government" can be defined by its objectives rather than by the scope of their activities. While the cited transversal competencies - activities - of schools define their means, the role criteria mapped during the interviews define the objectives to which those activities must aim for, and the conditions under which they should be performed.

By this point of view, the schools of government differ from traditional universities in the instrumental character of their educational activities. In addition, they are different from training units due to their higher degree of thematic specialization and by the strategic connection with government policies. They also differ in respect to the development and diffusion of research focused on the improvement of public services. The distinction from corporate universities, on the other hand, would mainly derive from the connection schools' present with the normative environment of the public administration characterized by the permeability to 
diffuse social objectives and formal links to governments and public policies, instead of aiming at the provision of competitive advantages in a given economic environment (Meister, 1999).

The emergence of Cooperation as one of the main criteria, reflects the relationship schools seek to maintain with other public organizations. Even formally, schools' regulations establish the creation of partnerships and cooperation agreements as their one of the main functions. The analysis of interviews reports points to the alignment of schools around common interests, which might reflect operational, legal, political as well as institutional constraints frequently faced by the schools.

\section{Conclusion: Challenges and future studies}

This exploratory study aimed at fostering comprehension about Schools of Government regarding their concept, formats, roles and activities. Through a comparative analysis of 17 Brazilian federal schools of government their distinct institutional characteristics, strategic guidelines and scope of activities, were analyzed and a classification typology was proposed. Nonetheless, schools seem to share a common identity and sense of purpose even though operating in diverse government areas. The shared views about what constitutes a school of government role poses an opportunity for a better definition of this concept and development of a more precise depiction of the professionalization activity as a key government policy.

\subsection{Challenges for institutionalization}

The relative ambiguity and around schools of government conceptualizations and roles is, at the same time, a cause and a consequence of some shortcomings. As a main critical factor, in general, all schools' interviewees believe that public sector culture tends to not consider training as a strategic process, in such way that bureaucracy professionalization is often neglected by senior public managers and government officials. This leads to an environment that imposes resistance and difficulties to ensure conditions and resources adequate to the competent performance of the schools.

The current legal framework comprising the civil service qualification is still vague, scant and unsystematic as a means for the creation of institutional mechanisms and policies that provide a well-adapted setting for educational activities. Many schools remain as functional departments in public organizations lacking technical, managerial and normative autonomy. Most schools report having insufficient financial resources or undergoing contingencies that undermine their planning 
and operational capacity. In regards to staffing, schools report not having enough personnel to meet their demands and face a shortage of specialized professionals for their specific activities (e.g., pedagogues, teachers, researchers).

The growing perspective of cooperative and joint political action by the schools in collective entities such as the SEGU emerges as a recent frontline aiming to promote a greater focus towards a more professionalized, practical and efficient civil service. Besides the cooperation efforts, schools expect that stronger regulation of the role of schools of governments serve as a source of legitimacy and autonomy. While the schools don't need to be turned in public agencies, a stronger legal framework would provide the capacity to expand activities beyond internal organizational needs, a common intention between some schools. This allows a better fulfillment of the schools of government's characteristics such as a larger "target audience", "strategic connection" and orientation towards public administration "objectives", besides the "formality" itself.

In this perspective, much can be achieved with further studies about schools of governments regarding respective institutional and organizational settings, common difficulties, impacts of educational activities organizational and public policies results, advantages and scale gains from cooperation arrangements, among others. Given the scarcity of studies regarding schools of government, this study stresses the need for a specific research agenda in order to support the development of managerial, institutional and cooperative arrangements among schools of government in regard of a greater qualification, innovation capacity and effectiveness in public service. In this respect, we point out some directions for theoretical development and future studies.

\subsection{Directions for theoretical development.}

Given the exploratory design of this study, the presented results were mostly based on systematization of emergent significant data resulting from document analysis and interviews in line with open-ended research questions. Nonetheless, we point out to well-established theoretical frameworks that might converge with presented data and provide better fundamentals for refining and furthering theory development.

In regard to the institutional dimension we note that many aspects converge with theoretical frameworks stemming from Verhoest et al. (2004) definition of types and dimensions of autonomy in public organizations. Aspects and variables relating to autonomy dimensions such as legal, financial, structural, managerial and technical autonomy are recurrently found to be relevant factors for the characterization of schools and the issues they face in their contexts. The studies originated from the 
cited seminal paper proved to be a useful theoretical and methodological design for the comparative study of public agencies, for instance as seen in Verhoest et al. (2010). In line with this model, future studies regarding institutional governance of schools of government can greatly advance on prescriptions and comprehension of how certain arrangements perform in different contexts. Comparative research and surveys such as the one presented by OECD (2017) may adopt a more detailed and thorough description to show how schools of government are more similar, or differ, across these dimensions. Given the scant literature on this subject, such an approach would potentially provide relevant theoretical development and practical guidance regarding the successful structuring of schools of government (Fernandes, 2007; Sigelman, 2006).

In relation to the strategic dimension, the HRD literature describes many traits akin to how schools of government perform, hence being suitable to better describe its functioning. Stewart et al (2010) define HRD functions reflect many of the key objectives regarding the roles of the schools of government such as the provision of specialized knowledge, shared services and formation of strategic partnerships (Stewart et al, 2010). The comparison of activities on the other hand, can foster developments in comparative HRD research (Wang \& Sun, 2012) and subsidize an evidence-based literature, bringing together context and best practices in contingent approaches for the public service. This interplay between theory, context and practice is regarded as one of the main advantages brought by comparative studies (Heady, 2006; Sigelman, 2006; Fitzpatrick et al, 2011)

The universe of Schools of Government is numerous both in the national and international context (OCDE, 2017). The growing efforts to understand and integrate these institutions in several level must rely on a more informed literature (Fernandes, 2017). The proposed agenda is but some of the possible theoretical fundamentals that converge with the findings in this study and should come into consideration for future research. These should, then, foster theoretical development about schools of government and render scientifically consistent prescriptions that provide valid and feasible recommendations to improve public services through a solid personnel development policy and more effective cooperative arrangements. 


\section{References}

BORINS, S. Trends in training public managers: a report on a commonwealth seminar. International Public Management Journal, v. 2, n. 2, pp. 299-314, 1999. BRASIL. Decreto no 5.707, de 23 de fevereiro de 2006. Institui a política e as diretrizes para o desenvolvimento de pessoal da administração pública federal direta, autárquica e fundacional, e regulamenta dispositivos da Lei $\mathrm{n}^{\circ} 8.112$, de 11 de dezembro de 1990. Presidência da República, Brasília, 2006.

CAMÕES, M. R. de S., \& MENESES, P. P. M. (2016). Gestão de Pessoas no Governo Federal: Análise da Implementação da Política Nacional de Desenvolvimento de Pessoal. Cadernos Enap, v. 45, Brasília: ENAP, 2016

CARVALHO, P. S. Rede Nacional de Escolas de Governo no Brasil: aprendizagens e desafios. In: XVII Congreso Internacional CLAD sobre la Reforma del Estado y de la Administración Pública, Cartagena de Indias. XVII CLAD, 2012.

CAVALCANTE, P.; CARVALHO, P. Profissionalização da burocracia federal brasileira (1995-2014): avanços e dilemas. Revista de Administração Pública, v. 51, n. 1, p. 1-26, 2017.

FERNANDES, C. C. C. Escolas de governo: origens e trajetória do tema no Brasil. In: FERNANDES, C. C. C.; PALOTTI, P. L. M.; CAMÕES, M. R. S. Escolas de governo: perfis, trajetórias e perspectivas. Cadernos Enap, N. 43, Vol.1, p. 15-33. Brasília: Enap, 2015.

Análise comparada das escolas de governo na literatura internacional: perfil, tendências e categorizações. In: FERNANDES, C. C. C.; PALOTTI, P. L. M.; CAMÕES, M. R. S. Escolas de governo: perfis, trajetórias e perspectivas. Cadernos ENAP, N. 43, Vol. 2, pp. 87-112, Brasília: Enap, 2017.

FITZPATRICK, J. et al. A New Look at Comparative Public Administration: Trends in Research and an Agenda for the Future. Public Administration Review, v. 71, n. 6, p. 821-830, 2011.

FONSECA, D. R. da; LEMOS, J. P.; CAMÕES, M. R. S; CAVALCANTE, P. L. C.; PALOTTI, P. L. M; AMORIM, S. A. As escolas de governo no Brasil: perfil e tendências in Fernandes. In: FERNANDES, C. C., PALOTTI, P. L. M.; CAMÕES, M. R. S. Escolas de governo: perfis, trajetórias e perspectivas. Cadernos Enap, N. 43, Vol.1, p. 35-86. Brasília: Enap, 2015.

HALL, D. (2002). Desenvolvimento gerencial no setor público: tendências internacionais e organizações-líderes. Cadernos Enap, V. 21. Brasília: Enap, 2002.

HEADY, F. Comparison in study of public administration. In: Ostenyo, E.; Lind, N. (eds.). Comparative Public Administration: The essential readings. Elsevier, p. 61128, 2006.

KOLISNICHENKO, N. National organizational arrangements for delivering public administration education and training. United Nations Department of Economic and Social Affairs (DESA), 2005. Available at: http://unpan1.un.org/intradoc/ groups/public/documents/un-dpadm/unpan034310.pdf

LUCKING, R. Civil service training in the context of public administration reform: 
a comparative study of selected countries from Central and Eastern Europe, and the former Soviet Union, (1989-2003): lessons on best practice in the approach to effective civil service training. United Nations. Sarajevo, Bosnia and Herzegovina. United Nations Development Program, 2003. Available at: <http:// unpan1.un.org/ intradoc/groups/public/documents/untc/unpan013648.pdf>

MEISTER, J. C. Educação corporativa. São Paulo: Makron Books, 1999.

Organisation for Economic Cooperation and Development (OECD). National Schools of Government: Building civil service capacity (Preliminary Version). Paris: OECD Publishing, 2017.

PACHECO, R. S. Escolas de governo como centros de excelência em gestão pública: a perspectiva da Enap - Brasil. Revista do Serviço Público, v. 53, n. 1, p. 77-88, janmar, 2002.

PACHECO, R. S. Escolas de governo: tendências e desafios - ENAP-Brasil em perspectiva comparada. Revista do Serviço Público, v. 51, n. 2, p. 35-53, 2000.

POLLITT, C.; OP DE BEECK, L. Training top civil servants: a comparative analysis [Report]. Catholic University of Leuven. 2010.

PRESCOTT, F. Research and curriculum development at National Schools of Government [Master's degree research project]. University of Victoria, 2014. Available at: http://hdl.handle.net/1828/5220

REICHARD, C. Education and training for new public management, International Public Management Journal, V. 1 N. 2, pp. 177-194, 1998.

ROSA, C. H. C.; HOLLANDA, P. P. T. M. Escolas de Governo no cenário internacional: estudo comparado. In: FERNANDES, C. C. C.; PALOTTI, P. L. M.; CAMÕES, M. R. S. Escolas de governo: perfis, trajetórias e perspectivas. Cadernos ENAP, N. 43, Vol. 2, pp. 113-204, Brasília: Enap, 2017.

SAVOIE, D. Public management development: A comparative perspective. International Journal of Public Sector Management, V. 3 N. 3, pp. 40-49, 1990.

SIGELMAN, L. In Search of Comparative Administration. In: Ostenyo, E.; Lind, N. (eds.). Comparative Public Administration: The essential readings. Elsevier, p. 9-16, 2006.

STEIN, E. et al. A política das políticas públicas: progresso econômico e social na América Latina. Relatório 2006. Ed. Campus, 2a edição, 2006.

STEWART, J. et al. Strategic HRD and the Learning and Development Function. In: GOLD et al. Human Resource Development: Theory and Practice. $1^{\text {st }}$ Ed. United Kingdom: Palgrave \& Mcmillan, 2010.

VERHOEST, K. et al. The study of organisational autonomy: a conceptual review. Public Admin. Dev, V. 24, pp. 101-118, 2004.

Autonomy and Control of State Agencies: Comparing States and Agencies, United Kingdom: Palgrave \& Mcmillan, 2010.

WANG, G. G.; SUN, J. Y. Toward a framework for comparative HRD research. European Journal of Training and Development, v. 36, n. 8, p. 791-808, 2012. 


\section{Diogo Ribeiro da Fonseca}

Instituição à qual está vinculado: UNB

Mestre e Doutorando em Administração na Universidade de Brasília.

Pesquisador do Grupo Projectum e do Centro de Pesquisa em Políticas Estratégicas de Gestão de Pessoas no Setor Público (CePGP/UnB).

Professor do Instituto Brasiliense de Direito Público.

\section{Marizaura Reis de Souza Camões}

Instituição à qual está vinculado: ENAP

Mestre e Doutoranda em Administração pela Universidade de Brasília.

Professora da Disciplina Trajetória da Gestão de Pessoas na Administração Pública Brasileira no curso de Especialização em Gestão de Pessoas no Setor Público

\section{Pedro Luiz Costa Cavalcante}

Instituição à qual está vinculado: IPEA

Mestre em Ciência Política pela Universidade de Brasília.

Doutor em Ciência Política pela Universidade de Brasília com pós-doutorado pela School of International and Public Affairs (SIPA) da Columbia University.

Coordenador de Estudos e Políticas de Estado do Instituto de Pesquisa Econômica Aplicada.

\section{Joselene Lemos}

Instituição à qual está vinculado: ENAP

Graduada em Química pela Universidade de Brasília.

Especialização em Gestão de Pessoas no Serviço Público pela Escola Nacional de Administração Pública.

\section{Pedro Palott}

Instituição à qual está vinculado: IPEA

Mestre em Ciência Política pela Universidade Federal de Minas Gerais.

Doutor em Ciência Política pela Universidade de Brasília.

Professor do Mestrado Profissional da Escola Nacional de Administração Pública.

Professor do Mestrado Profissional do Instituto Brasiliense de Direito Público 